\title{
PENGARUH UKURAN PERUSAHAAN DAN PROFITABILITAS TERHADAP AGRESIVITAS PAJAK PADA PERUSAHAAN MANUFAKTUR YANG LISTING DI BEI PERIODE TAHUN 2013-2017
}

\author{
Oleh: \\ Ari Wahyu Leksono ${ }^{1}$ \\ Setya Stanto Albertus ${ }^{2}$ \\ Rendika Vhalery ${ }^{3}$ \\ Fakultas Ilmu Pendidikan dan Pengetahuan Sosial \\ Program Studi Pendidikan Ekonomi \\ Universitas Indraprasta PGRI Jakarta

\section{Email:} \\ Ariwahyu.leksono@unindra.ac.id \\ Setyastantoalbertus@yahoo.co.id \\ Rendika.vhalery@unindra.ac.id
}

\begin{abstract}
Tax is a sector that plays an important role in the economy. This largest state revenue must continue to be increased optimally so that the pace of the country's growth and implementation of development can run well. But for business, people tax is considered as an investment burden. Therefore, it has become a natural thing if the company tries to avoid the tax burden. Management actions planned to reduce corporate tax payments through tax aggressiveness are common among companies around the world. This study aims to determine the effect of firm size and profitability on tax aggressiveness. The population and sample in this study were food and beverage sub-sector manufacturing companies listed on the Indonesia Stock Exchange (IDX) for the period 2013-2017. The sampling method used was purposive sampling. The analytical tool used is multiple linear regression. The results showed that partially the firm size and profitability (ROA) had a negative effect on tax aggressiveness. While the simultaneously firm size and profitability (ROA) have a positive effect on tax aggressiveness.
\end{abstract}

Keywords: Tax Aggressiveness, Company Size, Profitability. 


\begin{abstract}
ABSTRAK
Pajak merupakan sektor yang memegang peranan penting dalam perekonomian. Penerimaan negara terbesar ini harus terus ditingkatkan secara optimal agar laju pertumbuhan negara dan pelaksanaan pembangunan dapat berjalan dengan baik. Namun bagi pelaku bisnis pajak dianggap sebagai beban investasi. Oleh karena itu, sudah menjadi hal yang wajar apabila perusahaan berusaha untuk menghindari beban pajak. Tindakan manajemen yang direncanakan untuk memperkecil pembayaran pajak perusahaan melalui kegiatan agresivitas pajak menjadi hal umum di kalangan perusahaan di seluruh dunia. Penelitian ini bertujuan untuk mengetahui pengaruh ukuran perusahaan dan profitabilitas terhadap agresivitas pajak. Populasi dan sampel dalam penelitian ini adalah perusahaan manufaktur sub sektor food and beverage yang terdaftar di Bursa Efek Indonesia (BEI) periode 2013-2017. Metode pengambilan sampel yang digunakan adalah purposive sampling. Alat analisis yang digunakan adalah regresi linier berganda. Hasil penelitian menunjukkan bahwa secara parsial ukuran perusahaan dan profitabilitas (ROA) masing-masing berpengaruh secara negatif terhadap agresivitas pajak. Sedangkan secara simultan ukuran perusahaan dan profitabilitas (ROA) berpengaruh positif terhadap agresivitas pajak.
\end{abstract}

Kata Kunci: Agresivitas Pajak, Ukuran Perusahaan, Profitabilitas.

\title{
A. PENDAHULUAN
}

Pelaksanaan dan Pembangunan nasional di Indonesia sebagian besar diperoleh dari penerimaan pajak negara (langsung dan tidak langsung). Masyarakat Indonesia diwajibkan membayar pajak langsung atau tidak langsung agar laju pertumbuhan ekonomi dan pelaksanaan pembangunan nasional dapat berjalan dengan baik demi kesejahteraan negara. Dengan adanya pajak, perekonomian di Indonesia bisa menjadi lebih baik. Pajak dipandang mempunyai peranan penting karena dalam pos penerimaan Anggaran Pendapatan dan Belanja Negara (APBN) sumbangan pajak memiliki porsi yang lebih besar dibandingkan dengan penerimaan diluar pajak (Siregar dan Widyawati, 2016).

Penerimaan dari pajak harus terus ditingkatkan dan dioptimalkan agar laju pertumbuhan ekonomi negara dan pelaksanaan pembangunan dapat berjalan dengan baik. Disisi lain, para pelaku bisnis menggangap pajak sebagai beban investasi. Oleh sebab itu, sudah menjadi hal yang umum apabila perusahaan berusaha untuk menghindari beban pajak. Salah satu tindakan manajemen yang direncanakan untuk menghindari pajak perusahaan yang tinggi dilakukan agresivitas pajak (Lanis dan Richardson, 2013).

Menurut Nugraha dan Meiranto (2015) agresivitas pajak adalah kegiatan perencanaan pajak (tax planning) semua perusahaan yang terlibat dalam usaha mengurangi tingkat pajak yang efektif. Tax planning adalah proses pengendalian tindakan agar terhindar dari konsekwensi pengenaan pajak yang tidak dikehendaki (Kuriah dan Asyik, 2016). 
Terjadinya agresivitas pajak disebabkan oleh adanya perbedaan kepentingan antara si wajib pajak (perusahaan) dengan pemerintah. Pemerintah membutuhkan dana pajak untuk membiayai penyelenggaraan kegiatan-kegiatan yang dilakukan oleh pemerintah. Sedangkan perusahaan sebagai wajib pajak memandang pajak sebagai biaya tambahan yang harus dikeluarkan perusahaan. Dengan membayar pajak, akan mengurangi jumlah laba bersih yang akan diterima perusahaan. Oleh sebab itu pemilik perusahaan lebih tertarik untuk memanajemen perusahaan melakukan tindakan pajak agresif (Chen, et.al, 2008).

Agresivitas pajak dapat diukur dengan skala Effective Tax Rate (ETR) yang paling umum digunakan dalam beberapa literatur. Rentang nilai ETR yang dapat mengidentifikasi agresivitas pajak atau tidak. Contohnya, ETR yang rendah menunjukkan adanya agresivitas pajak. Beberapa perusahaan-perusahaan menghindari pajak dengan bermacam-macam cara seperti mengurangi penghasilan kena pajak perusahaan atau tetap menjaga laba akuntansi keuangan sehingga memiliki nilai ETR yang lebih rendah. Dengan demikian, ETR dapat difungsikan untuk mengaturr agresivitas pajak.

Agresivitas pajak dipengaruhi oleh beberapa faktor. Salah satunya adalah ukuran perusahaan (Tiaras dan Henryanto, 2015). Ukuran perusahaan merupakan suatu identitas perusahaan berdasarkan skala dimana besar kecilnya perusahaan dapat diklasifikasikan dalam berbagai cara, seperti melihat log total aktiva perusahaan, penjualan perusahaan, kapitalisasi pasar perusahaan dan lainnya (Leksono and Vhalery, 2018). Perusahaan dengan total aset yang tinggi adalah perusahaan berukuran besar dan sebaliknya (Yulia, 2013). Ukuran Perusahaan dapat menunjukkan kemampuan perusahaan pada tindakan pengembalian dan keputusan perpajakannya.

Ukuran perusahaan dapat menunjukkan kemampuan dan kestabilan perusahaan untuk melakukan aktivitas ekonominya. Semakin besar ukuran perusahaan maka semakin diawasi oleh pemerintah dan hal ini akan menimbulkan dua kemungkinan yaitu kecenderungan untuk berlaku patuh (compliances) atau tax avoidance yang merupakan aktivitas menghindari pajak (Kurniasih \& Sari, 2013). Berdasarkan hasil penelitian Tiaras dan Henryanto (2015), ukuran pajak mempengaruhi perilaku agresivitas pajak dan bersifat positif. Artinya, perusahaan skala besar pasti akan melakukantindakan agresivitas pajak.

Kegiatan penghindaran pajak yang dilakukan oleh perusahaan tentu saja berhubungan dengan profitabilitas yang dihasilkan. Hal ini senada dengan hasil penelitian yang diungkapkan oleh Andhari dan Sukartha (2017), bahwa profitabilitas berpengaruh positif terhadap agresivitas pajak. Profitabilitas merupakan salah satu acuan pengukuran bagi kinerja suatu perusahaan. Profitabilitas suatu perusahaan dapat mempengaruhi adanya agresivitas pajak. Perusahaan yang memiliki kemampuan untuk memperoleh keuntungan harus mempersiapkan pajak yang akan dibayarkan sebesar pendapatan yang diperoleh. Perusahaan yang memiliki profitabilitas yang tinggi akan membayar pajak lebih tinggi dari perusahaan yang memiliki tingkat profitabilitas yang lebih rendah (Lestari dan Febrianty, 2016). Profitabilitas diukur melalui Return on Assets (ROA) yang merupakan indikator untuk mengetahui performa keuangan perusahaan. Semakin tinggi nilai ROA, maka semakin bagus performa perusahaan 
dan sebaliknya, semakin rendah nilai ROA maka semakin buruk performa perusahaan. Perusahaan yang memperoleh laba diasumsikan tidak menerapkan agresivitas pajak karena mampu mengatur pendapatan dan pembayaran pajaknya (Gusti dan Alit, 2014).

Berdasarkan asumsi dan penelitian terdahulu, masih banyak keraguan yang dirasakan oleh peneliti. Seperti "apakah benar ukuran perusahaan mempengaruhi agresivitas pajak secara positif ?", atau "mungkinkah profitabilitas memberikan dampak sebaliknya terhadap agresivitas pajak pada perusahaan kecil atau besar?". Oleh sebab itu, untuk mengetahui apakah ukuran perusahaan dan profitabilitas berpengaruh terhadap agresivitas pajak pada perusahaan-perusahaan besar yang ada di Indonesia, peneliti mengangkat judul penelitian tentang "pengaruh ukuran perusahaan dan profitabilitas terhadap agresivitas pajak pada perusahaan manufaktur yang terdaftar di BEI periode tahun 2013-2017”.

\section{B. KAJIAN PUSTAKA}

\section{Teori Agensi}

Agensi merupakan sumber daya yang dimiliki oleh agent untuk kepentingan client. Merujuk pada pendapat Anthony dan Govindarajan (dalam Siagian, 2011) konsep agency theory merujuk pada hubungan antara principal dan agent. Prinsipal merupakan pengerak yang mempunyai kepentingan dan agent sebagai mitra akan melakukan pekerjaan prinsipal, termasuk melakukan pendelegasian otorisasi pengambilan keputusan. Contohnya, perusahaan yang mempunyai modal lembaran saham bertindak sebagai principal, dan CEO (Chief Executive Officer) perusahaan bertindak sebagai agent mereka. Perusahaan Pemegang lembaran saham akan mempekerjakan CEO perusahaan bertindak sesuai dengan kepentingan principal.

Hanggraeni (2014) mengatakan agency problem salah satunya disebabkan oleh adanya asymmetric information, yaitu informasi yang tidak seimbang antara principal dan agent. Sistem perpajakan di Indonesia menggunakan sistem penilaian sendiri (self-assessment system) yang dapat memberikan kesempatan kepada agent untuk menghitung penghasilan kena pajak minimal mungkin. Hal ini dilakukan oleh agent karena dengan melakukan manajemen pajak maka agent akan memperoleh keuntungan individu (personal) yang tidak bisa didapatkan dari kerjasama dengan principal.

\section{Pajak}

Haiwei (2014) mendefinisikan pajak sebagai iuran rakyat kepada kas negara berdasarkan undang-undang (keterpaksaan) dengan ada atau tidaknya mendapat jasa timbal balik. Uang dari pajak akan digunakan untuk:

1. Pembayaran gaji aparatur Negara seperti PNS, TNI, POLRI, hingga pembiayaan berbagai proyek pembangunan.

2. Subsidi listrik, BBM, publik seperti Bantuan Langsung Sementara Masyarakat (BLSM), Pengadaan beras miskin, serta Jaminan Kesehatan Masyarakat (Jamkesmas). 
3. Pembangunan nasional seperti fasilitas, sarana dan prasarana.

4. Pembiayaan lainnya dalam rangka meningkatkan kesejahteraan bagi seluruh rakyat indonesia.

\section{Agresivitas Pajak}

Agresivitas pajak merupakan tindakan yang umum dan sering terjadi saat ini dikalangan perusahaan-perusahaan besar di seluruh dunia. Tindakan agresivitas pajak bertujuan meminimalkan pajak perusahaan yang saat ini agresivitas pajak menjadi perhatian publik karena tidak sesuai dengan harapan masayarakat dan juga merugikan pemerintah. Hanlon dan Heitzman (dalam Nugraha, 2015) mendefinisikan agresivitas pajak sebagai tingkat yang paling akhir dari spektrum serangkaian perilaku perencanaan pajak. Tindakan agresivitas pajak dilakukan oleh perusahaan dikarenakan perusahan ingin meminimalkan beban pajak melalui tax planning activities yang bertujuan untuk memaksimalkan nilai perusahaan (Yoehana, 2013). Kewajiban pajak dapat diminimalisir melalui beberapa cara, seperti kegiatan memenuhi ketentuan perpajakan (lawful) melalui aktivitas penghindaran pajak maupun yang melanggar peraturan perpajakan (unlawful) melalui aktivitas penggelapan pajak dengan usaha mengurangi hutang pajak.

Cara untuk mengetahui perusahaan melakukan tindakan agresivitas pajak atau tidak yaitu dengan menggunakan skala pengukuran proksi Effective Tax Rate (ETR). Lanis dan Richardson (2012) menjelaskan bahwa ETR adalah proksi yang paling umum digunakan oleh peneliti atau ahli. Pengukuran proksi ETR dipandang sebagai indikator adanya aktivitas agresivitas pajak yang dilakukan perusahaan apabila memiliki nilai ETR yang mendekati nol. Apabila nilai ETR yang dimiliki oleh perusahaan semakin rendah maka tingkat agresivitas pajaknya semakin tinggi. Nilai ETR rendah akan menunjukan beban pajak penghasilan perusahaan lebih kecil daripada pendapatan sebelum pajak.

\section{Ukuran Perusahaan}

Ukuran perusahaan menunjukkan identitas perusahaan baik skala kecil maupun skala besar. Menurut Brigham \& Houston (2010) ukuran perusahaan adalah ukuran besar kecilnya sebuah perusahaan yang ditunjukan atau dinilai oleh total asset, total penjualan, jumlah laba, beban pajak dan lain-lain. Hartono (2013) menambahkan bahwa ukuran perusahaan merupakan besar kecilnya perusahaan yang dapat diukur dari total aktiva/besar harta perusahaan dengan menggunakan perhitungan nilai log total aktiva. Oleh karena itu, kualitas laporan keuangan harus transparan, terpercaya, dan terbebas dari manajemen laba karena dapat mengaburkan informasi yang tersedia. Terutama untuk informasi yang berkaitan dengan minimalisasi laba untuk meminimalkan pendapatan kena pajak sehingga pembayaran pajak menjadi minim.

Undang-Undang No. 20 Tahun 2008 menjelaskan kriteria ukuran perusahaan-perusahaan yang ada di Indonesia, secara rinci dapat dilihat sebagai berikut : 
Tabel 1. Kriteria Ukuran Perusahaan

\begin{tabular}{ccc}
\hline & \multicolumn{2}{c}{ Kriteria } \\
\cline { 2 - 3 } Ukuran Perusahaan & Assets & Penjualan Tahunan \\
& (Tidak termasuk tanah dan bangunan tempat usaha) & \\
\hline Usaha Mikro & Maks 50 juta & Maks 300 Juta \\
Usaha Kecil & $>50$ Juta-500 Juta & $>300$ juta-2.5 M \\
Usaha Menengah & $>10$ juta-10 M & $2.5 \mathrm{M}-50 \mathrm{M}$ \\
Usaha Besar & $>10 \mathrm{M}$ & $>50 \mathrm{M}$ \\
\hline Sumber : Data Olahan Primer 2019 & &
\end{tabular}

\section{Profitabilias}

Profitabilitas mendeskripsikan kinerja perusahaan untuk mendapatkan laba setelah dikurangi beban pajak dan beban-beban lainnya. Sartono (2010) menjelaskan bahwa profitabilitas merupakan manajemen perusahaan untuk mendapatkan laba yang berkaitan dengan total aktiva maupun modal serta penjualan. Profitabilitas merupakan hasil kinerja keuangan perusahaan untuk menghasilkan keuntungan dari manajemen aktiva perusahaan yang dikenal sebagai Return on Asset (ROA). ROA yang positif akan memberikan laba bagi perusahaan. Sedangkan ROA yang negatif mengindikasikan bahwa kinerja perusahaan kurang baik atau sangat buruk. ROA dinyatakan dalam bentuk persentase, semakin besar nilai persentase ROA maka semakin baik kinerja perusahaan. Semakin mendekati nilai nol persentase ROA maka semakin buruk kinerja perusahaan.

Semakin tinggi profitabilitas perusahaan akan semakin tinggi pula laba bersih perusahaan yang dihasilkan (Kurniasih dan Sari, 2013). Dapat diprediksi bahwa perusahaan yang memiliki tingkat profitabilitas yang tinggi akan selalu mentaati pembayaran pajak. Sedangkan perusahaan yang memiliki tingkat profitabilitas rendah, tidak akan taat pada pembayaran pajak perusahaan guna untuk mempertahankan aset perusahaan.

\section{Pengembangan Hipotesis}

\section{Pengaruh ukuran perusahaan terhadap agresivitas pajak}

Menurut Riyanto (2008) ukuran perusahaan dinilai dari besarnya nilai equity, nilai penjualan atau nilai aktiva sehingga perusahaan dapat dikategorikan. Perusahaan besar memiliki perencanaan pajak yang matang dan mengadopsi praktek akuntansi yang efektif untuk menurunkan ETR perusahaan (Rodriguez dan Arias, 2012). Aset yang dimiliki suatu perusahaan berhubungan dengan besar kecilnya perusahaan, semakin besar perusahaan maka semakin besar total aset yang dimilikinya. Aset akan mengalami penyusutan setiap tahunnya dan juga dapat mengurangi laba bersih perusahaan, sehingga dapat menurunkan beban pajak yang dibayarkan oleh perusahaan.

Berdasarlan uraian tersebut, maka hipotesis yang diajukan dalam penelitian ini adalah sebagai berikut:

$\mathrm{H}_{1}=$ Ukuran perusahaan berpengaruh negatif terhadap agresivitas pajak 


\section{Pengaruh profitabilitas terhadap agresivitas pajak}

Profitabilitas merupakan kemampuan pengelolaan perusahaan untuk memperoleh keuntungan dari operasional yang dilakukan perusahaan. Profitabilitas diukur menggunakan ROA yang mencerminkan kemampuan manajemen perusahaan dalam menghasilkan laba. Nilai ROA merupakan salah satu indikator bagi perusahaan dalam pencapaian laba perusahaan, sehingga perusahaan yang memiliki kesempatan untuk memposisikan diri dalam tax palnning dapat mengurangi jumlah beban pajak (Chen, et al., 2010). ini adalah:

Berdasarkan uraian diatas, hipotesis yang dapat diajukan dalam penelitian

$\mathrm{H}_{2}=$ Profitabilitas berpengaruh negatif terhadap agresivitas pajak .

\section{METODE PENELITIAN}

\section{Populasi dan Sampel}

Populasi dalam penelitian ini adalah perusahaan manufaktur yang terdaftar di Bursa Efek Indonesia (BEI) pada tahun 2013-2017. Teknik pengambilan sampel dalam penelitian ini menggunakan purposive sampling. Sampel dalam penelitian ini sebanyak 11 perusahaan manufaktur sub sektor food and beverages yang terdaftar di Bursa Efek Indonesia pada tahun 2013-2017.

\section{Jenis dan Teknik Pengumpulan Data}

Jenis data yang digunakan dalam penelitian ini menggunakan data sekunder. Metode pengumpulan data dalam penelitian ini yaitu dengan studi dokumentasi. Studi dokumentasi dalam penelitian ini di dapat dari data perusahaan yang terdaftar di Bursa Efek Indonesia (BEI) pada tahun 2013-2017.

\section{Definisi Konsep dan Pengumpulan Variabel}

\section{Agresivitas Pajak}

Agresivitas pajak merupakan keinginan perusahan untuk meminimalisir beban pajak melalui tax planning activities yang bertujuan memaksimalkan nilai perusahaan. Agresivitas pajak diukur dengan Effective Tax Rate (ETR) yaitu perbandingan antara pajak riil yang kita bayar dengan laba komersial sebelum pajak. Tarif pajak efektif atau ETR (Effective Tax Rate) dipakai untuk mengukur pajak yang dibayarkan sebagai proporsi dari pendapatan ekonomi (Ardyansah dan Zulaikha, 2014).

$$
E T R=\frac{\text { Beban pajak penghasilan }}{\text { Laba sebelum pajak }} \times 100 \%
$$




\section{Ukuran Perusahaan}

Ukuran perusahaan merupakan suatu ukuran yang dikelompokkan berdasarkan besar kecilnya perusahaan. Ukuran perusahaan diproksi dengan Ln total asset. Pemakaian natural $\log (\mathrm{Ln})$ dimaksudkan untuk mengurangi fluktuasi data yang berlebihan tanpa mengubah proporsi dari nilai asal yang sebenarnya (Nurfadilah, dkk, 2016).

\section{Size $=\log ($ Total Aset $)$}

\section{Profitabilitas}

Pofitabilitas merupakan kemampuan pengelolaan perusahaan untuk memperoleh laba maksimal. Dalam penelitian ini menggunakan Return Of Asset (ROA) untuk mengukur tingkat profitabilitas perusahaan, karena ROA menunjukkan efektifitas perusahaan dalam mengelola aktiva. Pengelolaan aktiva baik modal sendiri maupun dari modal pinjaman, investor akan melihat seberapa efektif perusahaan dalam mengelola aset (Rinaldi, 2015).

$$
R O A=\frac{\text { Laba bersih setelah pajak }}{\text { Total asset }} \times 100 \%
$$

\section{Model Penelitian}

Dalam penelitian ini, teknik yang digunakan adalah teknik analisis regresi linier berganda, karena variabel bebas dalam penelitian ini lebih dari satu. Persamaan regresi linier berganda dalam penelitian ini sebagai berikut:

$$
\mathbf{Y}=\boldsymbol{\alpha}+\boldsymbol{\beta} \mathbf{X}_{1}+\boldsymbol{\beta} \mathbf{X}_{2}+\mathbf{e}
$$

Keterangan:

Y : Effective Tax Rate

$\alpha \quad$ : Konstanta persamaan regresi

$\beta \quad$ : Koefisien regresi

$\mathrm{X}_{1}$ : Ukuran Perusahaan

$\mathrm{X}_{2}$ : Profitabilitas (ROA)

e : Error (nilai kesalahan)

\section{HASIL DAN PEMBAHASAN}

\section{Hasil Uji Asumsi Klasik}

Uji asumsi klasik dilakukan sebagai suatu syarat untuk melakukan uji regresi linear berganda. Apabila semua syarat terpenuhi maka dapat dilakukan uji regresi linear berganda secara perhitungan statistik parametrik. Tetapi, apabila semua syarat tidak terpenuhi maka dapat menggunakan perhitungan statistik secara non-parametrik untuk melanjutkannya. 
1. Hasil Uji Normalitas

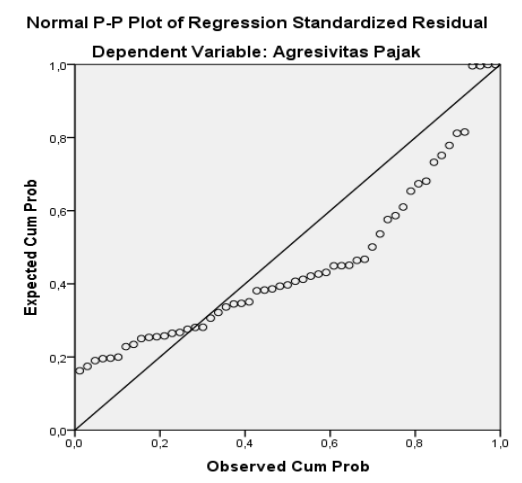

Gambar 1. Kurva P-plot Uji Normalitas

Berdasarkan gambar kurva diatas, deteksi normalitas dapat dilakukan dengan melihat kurva normal p-plot, penyebaran data (titik) pada sumbu diagonal dari grafik. Distribusi normal akan membentuk satu garis lurus diagonal dan ploating data akan dibandingkan dengan garis diagonal. Jika distribusi data normal maka garis yang menghubungkan data sesungguhnya akan mengikuti garis diagonalnya. Dan gambar kurva $p$-plot diatas menunjukkan data normal dan dapat dilanjutkan.

\section{Hasil Uji Multikolinearitas}

Tabel 2. Uji Multikolinearitas

\begin{tabular}{|c|c|c|c|}
\hline & \multirow{2}{*}{ Model } & \multicolumn{2}{|c|}{ Collinearity Statistics } \\
\hline & & Tolerance & VIF \\
\hline \multirow{3}{*}{1} & (Constant) & & \\
\hline & Ukuran Perusahaan & ,982 & 1,018 \\
\hline & Profitabilitas & ,982 & 1,018 \\
\hline
\end{tabular}

Pada tabel diatas menunjukkan bahwa ukuran perusahaan dan profitabilitas masing-masing mempunyai nilai tolerance sebesar 0.982 dan nilai VIF sebesar 1.018; nilai tolerance diatas 0.10 dan nilai VIF (Variance Inflation Factor) dibawah 10 sehingga dapat disimpulkan bahwa persamaan regresi terhindar dari masalah multikolinearitas dan dapat dilanjutkan pada tahap selanjutnya.

\section{Hasil Uji Heteroskedastisitas}

Berdasarkan hasil pengolahan data, maka hasil scatterplot dapat dilihat pada gambar berikut: 


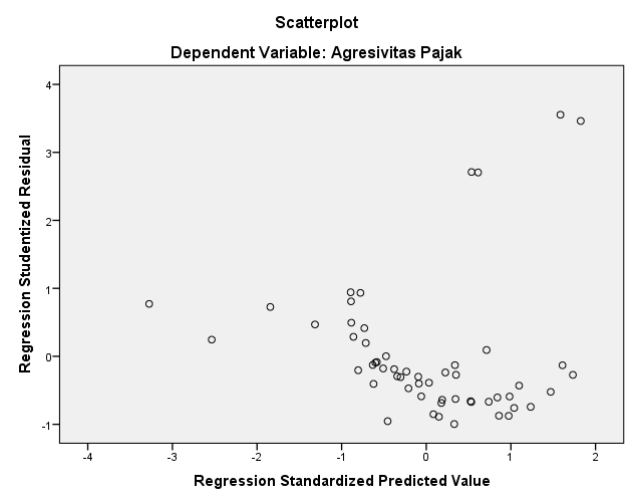

Gambar 2. Grafik Scatterplot

Dari grafik Scatterplot yang ada pada gambar diatas dapat dilihat bahwa titik-titik menyebar secara acak, tidak membentuk suatu pola serta tersebar baik diatas maupun dibawah angka nol pada sumbu Y. Hal ini dapat disimpulkan bahwa tidak terjadi heterokedastisitas pada model regresi dan dapat dilanjutkan.

\section{Hasil Uji Autokorelasi}

Salah satu ukuran dalam menentukan ada tidaknya masalah autokorelasi dengan Durbin-Watson yaitu sebagai berikut.

Tabel 3. Uji Autokorelasi

\begin{tabular}{lc}
\hline Model & \multicolumn{1}{c}{ Durbin-Watson } \\
\hline 1 &, 990 \\
\hline Predictors: (Constant), Profitabilitas, Ukuran Perusahaan \\
Dependent Variable: Agresivitas Pajak \\
Sumber : Hasil Output SPSS
\end{tabular}

Berdasarkan tabel model summary diatas diperoleh nilai Durbin Watsonsebesar 0.990. Dengan demikian, dapat dikatakan bahwa tidak terjadi autokorelasi karena nilai DW berada di antara -2 dan +2 atau $(-2<$ DW $<+2)$.

\section{Hasil Uji Hipotesis}

\section{Hasil Uji Regresi Linear Berganda}

Pengujian hipotesis dalam penelitian ini akan dilakukan dengan menggunakan model regresi linear berganda.

Tabel 4. Uji Regresi Linear Berganda

\begin{tabular}{|c|c|c|c|c|c|c|}
\hline \multirow{2}{*}{\multicolumn{2}{|c|}{ Model }} & \multicolumn{2}{|c|}{$\begin{array}{c}\text { Unstandardized } \\
\text { Coefficients }\end{array}$} & \multirow{2}{*}{$\begin{array}{c}\text { Standardized } \\
\text { Coefficients } \\
\text { Beta }\end{array}$} & \multirow[t]{2}{*}{$\mathrm{t}$} & \multirow[t]{2}{*}{ Sig. } \\
\hline & & B & Std. Error & & & \\
\hline 1 & (Constant) & 1,581 & ,433 & & 3,651 & ,001 \\
\hline & Ukuran Perusahaan &,- 453 &, 159 &,- 347 & $-2,856$ & ,006 \\
\hline & Profitabilitas (ROA) &,- 436 & 131 &,- 403 & $-3,320$ &, 002 \\
\hline
\end{tabular}


Berdasarkan tabel Coefficients diatas, persamaan regresi linier berganda dapat disusun sebagai berikut:

$$
\mathrm{Y}=1.581-0.453 \mathrm{X}_{1}-0.436 \mathrm{X}_{2}
$$

Koefisien-koefisien persamaan regresi linier berganda diatas dapat diartikan sebagai berikut:

1. Konstanta (a) sebesar 1.581 artinya apabila ukuran perusahaan dan profitabilitas nilainya sama dengan 0 , maka agresivitas pajak nilainya sebesar 1.581 .

2. Koefisien regresi untuk Ukuran Perusahaan $\left(\mathrm{X}_{1}\right)$ sebesar -0.453 . Koefisien regresi untuk Ukuran Perusahaan $\left(\mathrm{X}_{1}\right)$ memiliki nilai negatif yang menunjukkan perubahan yang tidak searah antara Ukuran Perusahaan dengan agresivitas pajak artinya setiap Ukuran Perusahaan mengalami kenaikan 1, maka Agresivitas pajak (Y) akan mengalami penurunan sebesar 0.453 dengan asumsi Profitabilitas (ROA) nilainya tetap.

3. Koefisien regresi untuk Profitabilitas $\left(\mathrm{X}_{2}\right)$ sebesar -0.436. Koefisien regresi untuk Profitabilitas $\left(\mathrm{X}_{2}\right)$ memiliki nilai negatif yang menunjukkan perubahan yang tidak searah antara Profitabilitas (ROA) dengan agresivitas pajak artinya setiap nilai Profitabilitas (ROA) mengalami kenaikan 1, maka Agresivitas pajak (Y) akan mengalami penurunan sebesar 0.436 .

\section{Hasil Uji Koefisien Determinasi}

Hasil uji koefisien determinasi dapat dilihat pada tabel dibawah ini.

Tabel 5. Hasil Uji Koefisien Determinasi

\begin{tabular}{|c|c|c|c|c|}
\hline Model & $\mathbf{R}$ & R Square & Adjusted R Square & $\begin{array}{l}\text { Std. Error of } \\
\text { the Estimate }\end{array}$ \\
\hline 1 & $496^{\mathrm{a}}$ & 246 & 217 & ,117567 \\
\hline
\end{tabular}

Berdasarkan tabel diatas dapat dijelaskan bahwa nilai koefisien determinasi R-Square sebesar 0.246 atau $24.6 \%$ yang artinya variasi variabel independen yang digunakan dalam model yaitu Ukuran Perusahaan $\left(\mathrm{X}_{1}\right)$ dan Profitabilitas $\left(\mathrm{X}_{2}\right)$ mampu mempengaruhi variabel dependen yaitu Agresivitas pajak (Y) sebesar 24.6\%. Sedangkan sisanya sebesar $75.4 \%$ dipengaruhi oleh faktor-faktor lain di luar variabel yang diteliti. 


\section{Hasil Uji t (Parsial)}

Tabel 6. Hasil Uji t (Parsial)

\begin{tabular}{|c|c|c|c|c|c|c|}
\hline \multirow{2}{*}{\multicolumn{2}{|c|}{ Model }} & \multicolumn{2}{|c|}{$\begin{array}{l}\text { Unstandardized } \\
\text { Coefficients }\end{array}$} & \multirow{2}{*}{$\begin{array}{c}\begin{array}{c}\text { Standardized } \\
\text { Coefficients }\end{array} \\
\text { Beta } \\
\end{array}$} & \multirow[t]{2}{*}{$\mathbf{t}$} & \multirow[t]{2}{*}{ Sig. } \\
\hline & & B & Std. Error & & & \\
\hline \multirow[t]{3}{*}{1} & (Constant) & 1,581 & ,433 & & 3,651 & 001 \\
\hline & Ukuran Perusahaan &,- 453 & 159 &,- 347 & $-2,856$ &, 006 \\
\hline & Profitabilitas (ROA) &,- 436 & 131 &,- 403 & $-3,320$ &, 002 \\
\hline
\end{tabular}

Berdasarkan tabel hasil uji t dapat disimpulkan sebagai berikut:

\section{a. Hasil Uji Hipotesis 1: Pengaruh Ukuran Perusahaan Terhadap Agresivitas Pajak}

Berdasarkan hasil Uji-t menunjukkan bahwa nilai $t_{\text {hitung }}$ sebesar 2,856 dengan nilai signifikansi variabel ukuran perusahaan sebesar $0.006<0.05$ yang artinya $\mathrm{H}_{0}$ ditolak dan $\mathrm{Ha}_{1}$ diterima. Artinya ukuran perusahaan berpengaruh negatif terhadap agresivitas pajak.

\section{b. Hasil Uji Hipotesis 2: Pengaruh Profitabilitas (Roa) Terhadap Agresivitas Pajak}

Berdasarkan hasil Uji-t menunjukkan bahwa nilai $t_{\text {hit }}$ sebesar 3,320 dengan nilai signifikansi variabel profitabilitas (ROA)sebesar $0.002<0.05$ yang berarti $\mathrm{H}_{0}$ ditolak dan $\mathrm{Ha}_{2}$ diterima. Artinya profitabilitas (ROA) berpengaruh negatif terhadap Agresivitas pajak.

\section{Hasil Uji F (Simultan)}

Tabel 7. Hasil Uji F (Simultan)

\begin{tabular}{lcccccc}
\hline & Model & Sum of Squares & Df & Mean Square & F & Sig. \\
\hline $1 \quad$ Regression &, 234 & 2 &, 117 & 8,472 &, 001 \\
& Residual &, 719 & 52 &, 014 & & \\
$\quad$ Total &, 953 & 54 & & & \\
\\
Dependent Variable: Agresivitas Pajak \\
Predictors: (Constant), Profitabilitas, Ukuran Perusahaan \\
Sumber: Hasil Output SPSS
\end{tabular}

Berdasarkan hasil uji $\mathrm{F}$ (simultan) diatas menunjukkan bahwa nilai $\mathrm{F}_{\text {hitung }}$ diperoleh sebesar 8.472 dengan tingkat signifikansi $0.001<0.05$, sehingga dapat dikatakan bahwa Ukuran Perusahaan dan Profitabilitas berpengaruh secara simultan terhadap Agresivitas Pajak.

\section{E. SIMPULAN}

Berdasarkan hasil analisis dan pembahasan maka dapat disimpulkan sebagai berikut:

1. Ukuran perusahaan berpengaruh negatif terhadap agresivitas pajak.

2. Profitabilitas berpengaruh negatif terhadap agresivitas pajak. 
3. Ukuran perusahaan dan profitabilitas berpengaruh terhadap agresivitas pajak.

\section{DAFTAR PUSTAKA}

Andhari, Putu Ayu Seri dan Sukartha, I Made. 2017. Pengaruh Pengungkapan Corporate Social Responsibility, Profitabilitas, Inventory Intensity, Capital Intensity, Dan Laverage Pada Agresivitas Pajak. E-jurnal akuntansi. Hal. 2115-2142.

Ardyansah, Danis dan Zulaikha, 2014. Pengaruh Size, Leverage, Profitability, Capital Intensity Ratio, dan Komisaris Independen Terhadap Effective Tax Rate, Diponegoro Journal of Accounting, ISSN (Online), Vol. 3, No. 2, 1-9.

Bringham dan Houston. 2010. Dasar-Dasar Manajemen Keuangan. Buku 1 (Edisi 11). Jakarta: Salemba Empat.

Chen, Shuping et., al. 2008. Are Family Firms more Tax Aggressive than NonFamily Firms?. Journal of Financial Economics.

Hanggraeni, D. 2014. Manajemen Risiko Perusahaan Terintegrasi (Enterprise Risk Management) dan Good Corporate Governance. Penerbit Universitas Indonesia. Jakarta.

Hartono, Jogiyanto. 2013. Teori Portofolio dan Analisis Investasi. Edisi Kelima. BPFE. Yogyakarta.

Kuriah, Hanik Lailatul dan Fadjrih Asyik. 2016. Pengaruh Karakteristik Perusahaan dan Corporate Social Responsibility Terhadap Agresivitas Pajak. Jurnal Ilmu dan Riset Akuntansi, Vol.5, No.3, ISSN: 2460-0585.

Kurniasih, T., \& Sari, M.M.R. 2013. Pengaruh Return On Assets, Leverage, Corporate Governance, Ukuran Perusahaan dan Kompensasi Rugi Fiskal pada Tax Avoidance. Buletin Studi Ekonomi, 1 (18), 58-66.

Lanis, R. and G. Richardson. 2012. "Corporate Social Responsibility and Tax Aggressiveness: An Empirical Analysis”. J. Account. Public Policy, pp.86108.

Leksono, A. W., \&Valery, R. The Effect of Good Corporate Governance Mechanism and Financial Performance on Firm Value of Banking Sector Listed on Indonesia Stock Exchange (BEI) Period of 2012-2016. International Journal of Innovative Science and Research Technology, 3(9), 535-540

Maharani, I Gusti Ayu Cahya dan Ketut Alit Suardana. 2014. Pengaruh Corporate Governance, Profitabilitas, dan Karakteristik Eksekutif Tax Avoidance Perusahaan Manufaktur. E-Jurnal Akuntansi Universitas Udayana, 9 (2), 525-539. ISSN: 2302-8556. 
Nugraha, N.B., dan Meiranto, W., 2015, pengaruh Corporate Social Responsibility, Ukuran Perusahaan, Profitabilitas, Leverage, dan Capital Intensity Terhadap Agresivitas Pajak, Diponegoro Journal Of Accounting, Vol. 4, No. 4.

Nurfadillah, dkk. 2016. Pengaruh Leverage, Ukuran Perusahaan, dan Kualitas audit terhadap Penghindaran Pajak. Syariah Paper Accounting FEB UMS. ISSN 2460-0784.

Putri, Citra Lestari dan Maya Febrianty Lautania. 2016. Pengaruh Capital Intensity Ratio, Inventory Intensity ratio, Ownership Structure dan Profitability Terhadap Effective Tax Rate (ETR) (Studi pada perusahaan Manufaktur yang Terdaftar di Bursa Efek Indoneisa Tahun 2011-2014). Jurnal Ilmiah Mahasiswa Ekonomi Akuntansi. Vol. 1, No,1, Halaman 101119.

Riyanto, Bambang. 2008. Dasar-dasar Pembelanjaan Perusahaan. Yogyakarta: Penerbit GPFE.

Rodriguez and Arias. 2013. Do Business Characteristics Determine an Effective Tax Rate?. The Chinese Economy, 45 (6), 60-83.

Siagian, Sondang P. 2011. Manajemen Sumber Daya Manusia. Jakarta : Bumi Aksara.

Siregar, Rifka dan Widyawati, Dini. 2016. Pengaruh Karakteristik Perusahaan Terhadap Penghindaran Pajak Pada Perusahaan Manufaktur Di BEI. Jurnal ilmu dan riset akuntansi. Volume 5 Nomor 2, Februari 2016, ISSN: 24600585 .

Tiaras, Irvan dan Henryanto Wijaya. 2015. Pengaruh likuiditas, leverage, manajemen laba, komisaris independen, dan ukuran pajak terhadap agresivitas pajak. Jurnal Akuntansi. Vol. XIX, No. 03., Hal. 380-397.

Tjendraputra, Haiwei. 2014. Pengaruh Moderniasi Sistem Administrasi Perpajakan Terhadap Tingkat Kepatuhan Pengusaha Kena Pajak Pada Lokasi Bisnis Dan Perdagangan Di Kawasan Tanjung Perak Surabaya. Undergraduate Thesys, Widya Mandala Catholic University.

Yoehana, Maretta. 2013. "Analisis Pengaruh Corporate Social Responsibility terhadap Agresivitas Pajak." Diponegoro Journal of Accounting.

Yulia, Mona. 2013. Pengaruh Ukuran Perusahaan, Profitabilitas, Financial Leverage, dan Nilai Saham Terhadap Perataan Laba (Income Smoothing) Pada Perusahaan Manufaktur, Keuangan, dan Pertambangan Yang Terdaftar Di BEI, Jurnal Ilmiah Akuntansi, Vol. 1, No. 1, Universitas Padang. 